ISLLAC

Journal of Intensive Studies on Language, Literature, Art, and Culture

Vol. 1 No. 1 September 2017

\title{
DEVELOPING VOCATIONAL-BASED LEARNING MATERIALS TO \\ WRITE SCIENTIFIC PAPERS TO IMPROVE THE POLYTECHNIC STUDENTS' ACADEMIC WRITING SKILLS IN INDONESIAN LANGUAGE COURSE
}

\author{
Moh. Thamrin \\ thamrin.ham@gmail.com \\ State Polytechnic of Malang
}

\begin{abstract}
This research seeks to develop vocational-based learning materials to write scientific papers, particularly tailored to improve the Polytechnic students' academic writing skills entailed in Indonesian Language course. This research employed the combination of two modified instructional design models, namely, R2D2 (recursive, reflective, design, and development) and R\&D (research and development. From the amalgamation of the two developmental models, the researcher obtained the development procedures as follows: (1) preliminary study, (2) determination, and (3) design and development. The learning materials encompass 5 learning competencies, namely, (1) writing scientific works, (2) scientific articles, (3) writing apprentice work reports, (4) writing citations and references, and (5) editing the language employed in scientific works. Those five competencies are developed in accordance with the characteristics of learning materials for Polytechnic students, namely, (1) encompassing competence on scientific works writing; (2) installing understanding on the nature of scientific works; (3) designing or composing scientific works; (4) explicating steps required to write scientific papers as standard operating procedure (SOP); (5) practicing writing scientific papers; (6) assessing the outcomes of the practice by using instruments.
\end{abstract}

Keywords: learning materials, vocational, scientific works

\section{INTRODUCTION}

That learning materials play an essential role certainly is indubitable. In addition, to serve as strategic media in transforming students' knowledge, skills, values of life, cultures, and characters (morals and personalities), they can contribute greatly to the students' achievements. The World Bank Report (1989) on Indonesia, for instance, demonstrates that the level of learning material ownership, along with 
ISLLAC

Journal of Intensive Studies on Language, Literature, Art, and Culture

Vol. 1 No. 1 September 2017

other facilities, positively correlates with the level of learning achievement. The report attests the results of a study conducted by Heyneman et al. (in Thamrin, 2014; Patrick, 1988, Cunningswort, 1995) asserting that there is a significant correlation between learning materials and learning achievement of students. Moreover, the learning materials are of use to both students and lecturers in the learning process (Ansary, 2002).

Furthermore, the ability to write scientific papers is an essential skill for students. Wahab and Lestari (1999) affirm that writing scientific papers is an activity from which students, as part of the scientific community at university, cannot avert their attention. With regard to the result of focus group discussion (FGD) with the students and the lecturers, it appears that the students still find it difficult to meet the competence required in writing scientific papers. The unavailability of suitable learning materials, particularly those providing clear guides to write scientific papers with vocational features, serves as one of the contributing factors. Given the importance and complexity of writing skills, it is, therefore, necessary to intensively enhance the students' writing skills. Responding to such a situation, the substance of the present study is integrated with the employment of Indonesian through listening, speaking, reading and writing skills, the focus of which is on academic writing skills.

This research attempts to continue the studies that have been carried out in the pursuit of learning materials development. Take, for instance, a study by Thamrin (PHD, 2013) which is aimed at developing learning materials particularly tailored to scientific papers writing. This research, thus, is projected to yield such learning materials in accordance with the character of Polytechnic students. The vocationalbased learning materials are designed to adequately entail the learning activities intended for the students and mentoring activities, along with the reinforcement, undertaken by the lecturers.

There is an interrelated relationship between the learning materials for the purpose of scientific papers writing for Polytechnic students, Polytechnic education, 
ISLLAC

Journal of Intensive Studies on Language, Literature, Art, and Culture

Vol. 1 No. 1 September 2017

and learning materials in Polytechnic. The linkage can be seen from the characteristics of each component above.

The aforementioned interrelationship is displayed in Figure 1.

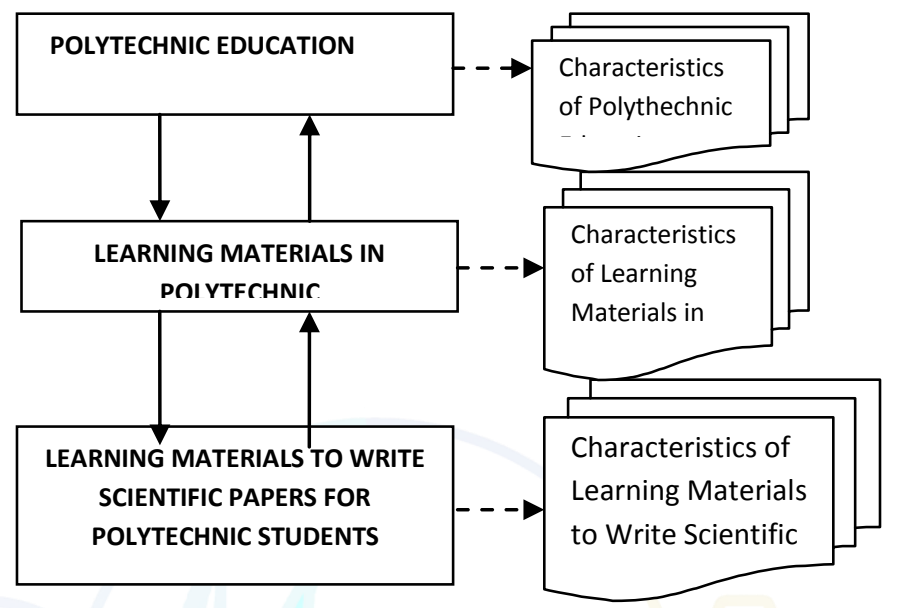

Figure 1 The Interrelation of Learning Materials and Polytechnic Education

Referring to the interrelationship between vocational education, vocational learning materials and learning materials to write scientific papers, as well as their characteristics, the characteristics of learning materials to write vocational-based scientific papers are spelled out as follows: (1) the learning materials are elaborated based on the competencies and indicators of learning to write targeted scientific papers; (2) the understanding of the nature of scientific works is done by reading theories and observing examples of scientific works; (3) such an observation is intended as a means to enable students to understand the form of scientific works as well as to be employed as a modeling text; (4) the steps of writing scientific papers that can be used by the students as standard operating procedures are explicated; (5) the assessment of the results of the practice can be done independently by the students and the lecturers by utilizing assessment guides in the form of prepared instruments; (6) enjoyable and student-centered learning is highly encouraged. 
ISLLAC

Journal of Intensive Studies on Language, Literature, Art, and Culture

Vol. 1 No. 1 September 2017

There are two concepts that can be used as a foundation to elucidate the writing of scientific papers, the concept of writing and scientific work. Writing is a communication activity based on an active and constructive thinking process attempted to pour ideas, opinions, feelings, desires, wills, and information into written forms, the main purpose of which is to be communicated to others by using an effective language. Such a notion, in line with MacArthur's (2007) opinion of writing, suggests that writing is a tool for conveying one's ideas.

With regard to scientific papers writing, Brusaw et al (1982) states that there are six components to consider: (1) selecting and limiting topics, (2) gathering sufficient data available, (3) identifying materials to be written, (4) classifying data, (5) determining a writing frame, and (6) developing writing strategies.

Writing - including writing scientific papers - is a series of activities undertaken that encompasses three stages, namely, preparation, content development, and the perfection of the composition. These three stages refer to process-oriented writing activities. As a process-oriented approach to writing, Barrs (1983), Ellis (1989), Proett and Gill (1986) divide the writing activities into several phases entailing prewriting, drafting, revising, and editing.

\section{METHOD}

This research employed the combination of two modified instructional design models, namely, R2D2 (recursive, reflective, design, and development) and $\mathrm{R} \& \mathrm{D}$ (research and development). From the amalgamation of the two developmental models, the researcher obtained the development procedures as follows: (1) preliminary study, (2) determination, and (3) design and development. 
ISLLAC

Journal of Intensive Studies on Language, Literature, Art, and Culture

Vol. 1 No. 1 September 2017

The research procedures are displayed in Figure 2.

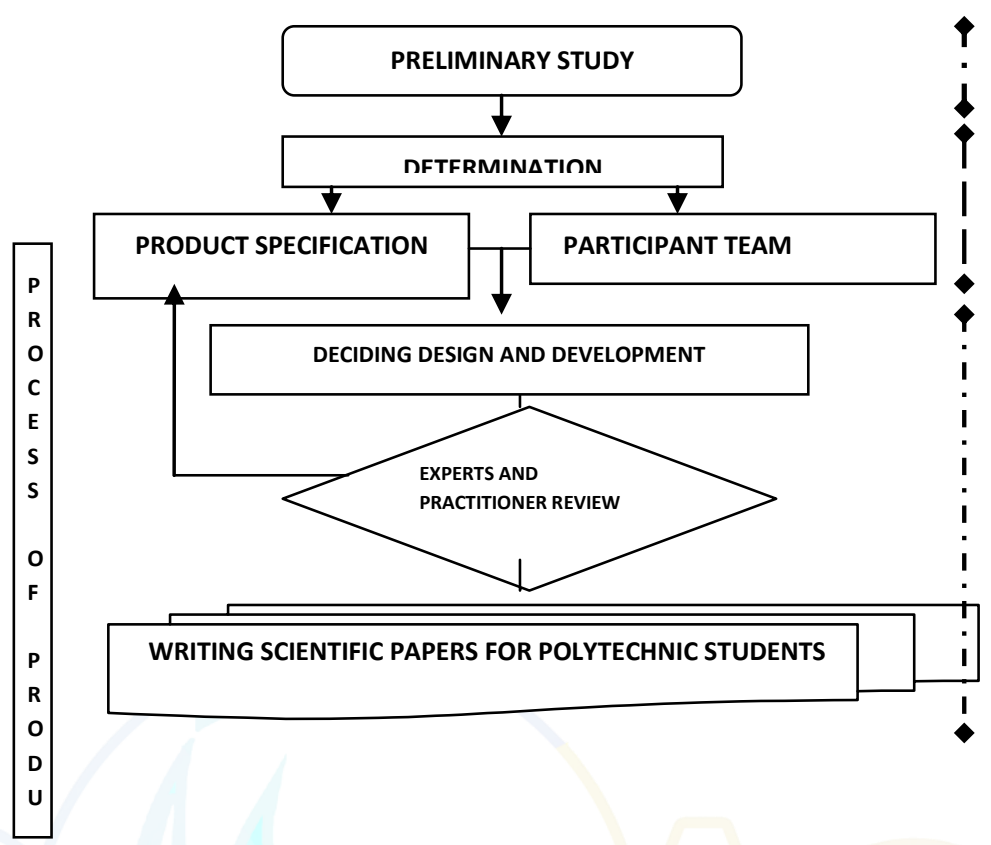

Figure 2: Research Procedures

There is two main activities in the development process, namely, (1) design determination and (2) product development. The process of determining the design was done by administering the FGD with Indonesian lecturers and students by considering the preliminary study (needs analysis). The next step was projected as validation testing gained from practitioners and experts on Indonesian as well as vocational learning. Based on the results of FGD and practitioners and experts validation, the design of learning materials to write scientific papers for Polytechnic students are as follows: (1) the competence that the students have to attain entails the ability to write scientific works, scientific articles, and apprentice work reports, and (2) the structure of the learning materials encompasses several stages as understanding the nature of scientific works, formulating scientific works, understanding the steps of writing scientific papers, the practice of writing scientific papers, and assessing the results of the practice of writing scientific papers. 
ISLLAC

Journal of Intensive Studies on Language, Literature, Art, and Culture

Vol. 1 No. 1 September 2017

In accordance with the development procedures, the process of materials development in this research includes (1) blueprint determination, (2) development of learning activities and (4) development of evaluation.

The blueprint of the materials development is based on the following considerations: (1) the required scientific writing materials are beneficial to the students, for it serves the purpose of a course on Indonesian Language and helps the students use the competence when dealing with scientific papers writing, apprentice work report, and scientific articles writing upon the completion of their final reports or theses; (2) it considers the contents of the curriculum for Indonesian Language course; (3) it also takes into account the results of FGD with students, lecturers of Indonesian Language course, and other lecturers teaching other courses.

In March 2017 the researcher started to prepare the specification of learning materials to write scientific papers for Polytechnic students. The steps taken comprise (1) determining the competence, (2) developing indicators of achievement of the competence, (3) determining learning topics based on the competence and indicators of achievement, and (4) determining the order of presentation of the learning topics.

The development of learning activities embedded in the learning materials has a great influence on learning. The learning activities developed for Polytechnic students is designed to improve the students' writing competence. As explained earlier, the hallmark of vocational learning lies in practical activities, so the learning activities developed should support these activities.

After conducting the FGD with the lecturers, it was found that activities supporting the practical activities include: (1) observing pictures, (2) understanding the steps of writing, and (3) writing practice. To ensure that the observation activities by students correspond with the objectives, a guideline is provided.

After observing images or pictures of scientific papers, the next step is developing writing steps. This section informs the stages of writing that should be 189 | 
ISLLAC

Journal of Intensive Studies on Language, Literature, Art, and Culture

Vol. 1 No. 1 September 2017

done by students when they make a practice to write scientific papers. The writing step is a standard operating procedure (SOP) that students must perform like what students have to do in workshop and lab work practices. Referring to SOP as a guideline in practicing to write is a simple way to achieve the skills of writing scientific papers. The next step is to develop learning activities related to the practice of writing scientific papers. The practice is also guided by the steps that must be accomplished by the students during the practice of writing scientific papers.

The purpose of evaluation development is to determine the learning outcomes achieved by the students. The evaluation in this textbook is developed in the form of instruments so that the students can use them to measure the tasks that have been done on their own. In such a way, the students can always independently enhance their competency achievements.

\section{FINDINGS AND DISCUSSION}

\section{Findings}

The research findings consist of two components, namely, (1) the specification of learning materials and (2) learning materials product. The product specification of learning materials to write scientific papers is based on the results of the study of vocational learning theories and consideration to the results of the examination of experts on Polytechnic education technology, experts on Indonesian learners, and practitioners. The review from the experts and the practitioners was employed as a consideration to improve the product specifications. The results of the refinement yielded (1) a product in the form of learning materials to write scientific papers for Polytechnic students and (2) a product particularly designed to meet the characteristic of learning in Polytechnic which places a great emphasis on practice. The theory presented fully supports the practice of improving the scientific papers writing skills; (3) broadly speaking, the sequence of the learning materials encompasses essence, an outline of the basic competence, an observation of scientific texts, and practice; (4) to achieve the competence, the students carry out activities to understand the nature of scientific papers by observing the texts; (5) to 190 | 
ISLLAC

Journal of Intensive Studies on Language, Literature, Art, and Culture

Vol. 1 No. 1 September 2017

practice writing scientific papers, the learning activities proceed with understanding the steps, followed by practice, and end with self-assessment using the prepared instruments; and (6) the developed learning material is packed in the form of a book or an e-book version.

The development of learning materials to write scientific papers contains four sub-discussion, namely, (1) understanding the nature of scientific work, (2) designing scientific papers, (3) preparing the introduction, (4) preparing the discussion, (5) arranging the cover, and (6) compiling a list of references. These six sub-sections are elucidated in the following description.

The presentation of the materials proceeds with exposing the nature of scientific work. In this part, the definition and the nature of scientific works are presented, followed by the presentation of types of reasoning used in such a setting, and the observation of the texts. In the next sub-sections encompassing preparing the introductory section, the discussion section, and the cover section, and compiling a list of references always comprise of activities as follows: (1) observing, (2) preparing the writing of scientific papers, (3) determining the steps, (4) practicing writing, and (5) assessing the results of the practice based on the instruments already provided.

\section{Discussion}

\section{Description of Learning Material Product Specification}

The product specification was prepared by considering the results of experts' and practitioners' review. The validation entailed comments, criticism, suggestions, and assessment of the developed product. The review was furthermore employed as a consideration to improve the product specifications.

In accordance with the vocational learning experts' validation on the specifications of the product, it generated a result stating that it generally is feasible 
ISLLAC

Journal of Intensive Studies on Language, Literature, Art, and Culture

Vol. 1 No. 1 September 2017

to be used as a blueprint for learning materials development. Moreover, responding to the experts' suggestions, some sections have been considerably revised.

Pertaining to the experts' review on the content and the presentation of the learning materials in the product, the results comprise of following aspects: (1) the material presented in the teaching materials is in accordance with the objectives and reflects the elaboration that supports the achievement of the objectives; (2) the presentation of the concept is sufficient as the teaching material is purposefully arranged to enable the students to write scientific papers, not only learning about scientific works; (3) pictures and cases presented are in accordance with the real and situational context in the Polytechnic; (4) practical assignments have been assigned to groups and individuals;

The systematic presentation of each chapter is consistent, as evidenced by every unit proceeding with nature, the observation, the procedure, and the scientific papers writing practice; it ends with self-assessment activities.

The general comments gained from practitioners state that (1) one of the advantages of this product is the distinctive characteristic of the learning steps and (2) it does not teach about scientific papers but learn to write scientific papers.

\section{Description of Instructional Materials Product}

\section{Learning Component Section}

The present product begins with an introduction. Moreover, there are four things that need to be understood by the students in utilizing teaching materials, namely, (1) understanding the purpose of studying the book, (2) knowing the expected results, (3) knowing the benefits of studying the book, and (4) implementing appropriate strategies in using the book.

The expected results include increasing the level of competence in writing scientific papers. It endorses the opinion of Tomskin (1990) asserting that the learning materials can determine the success of learning as a whole. In order to 192 | 
ISLLAC

Journal of Intensive Studies on Language, Literature, Art, and Culture

Vol. 1 No. 1 September 2017

obtain effective results, the learning strategies refer to several components such as to understand the concepts presented, design or compose scientific papers, observe texts, and practice writing scientific papers.

Based on the description above, this section can be regarded as a guideline for using the book in the process of learning to write scientific papers for Polytechnic students. The guidance plays an important position in learning. Therefore, it needs to be carefully prepared so that the learning process can reach the target.

The learning materials for writing scientific papers contain several competencies, namely, (1) writing scientific papers, (2) scientific articles, (3) apprentice work reports, (4) a lost of citations and references, and (5) editing languages employed in scientific papers. In general, every competency in writing a scientific paper contains four subsections, namely, (1) understanding the nature of the scientific work, (2) composing the scientific work, (3) preparing the introduction, (4) preparing the discussion, (5) arranging the cover, and (6) compiling a reference list. These six subsections are elucidated in the following description.

The presentation of the materials proceeds with exposing the nature of scientific work. In this part, the definition and the nature of scientific works are presented, followed by the presentation of types of reasoning used in such a setting, and the observation of the texts. In the next sub-sections encompassing preparing the introductory section, the discussion section, and the closing section, and compiling a list of references always comprise of activities as follows: (1) observing, (2) preparing the writing of scientific papers, (3) determining the steps, (4) practicing the writing, and (5) assessing the results of the practice based on the instruments already provided. The five activities are described as follows.

Seven instructions or questions are formulated to guide the students in observing the texts. The text observation includes a series of activities: questions and answers session, discussions, presentations, and reinforcement from the lecturers. 
ISLLAC

Journal of Intensive Studies on Language, Literature, Art, and Culture

Vol. 1 No. 1 September 2017

This observation instruction is projected to make the students' activity align with the learning objectives.

The series of observing activities are expected to expand the students' horizon about scientific work. To better comprehend the material, the observation material provides marginal notes which are very helpful for the students, the function of which is to define a macro understanding of scientific work. The observation materials used in this learning materials development are the students' scientific work. Thus, it is supposed that the students would feel familiar with the scientific work being observed. In addition, the students are supposed to immediately adapt the observed study as a model to be employed in their scientific work writing. The figure of marginal note can be seen in the following image:

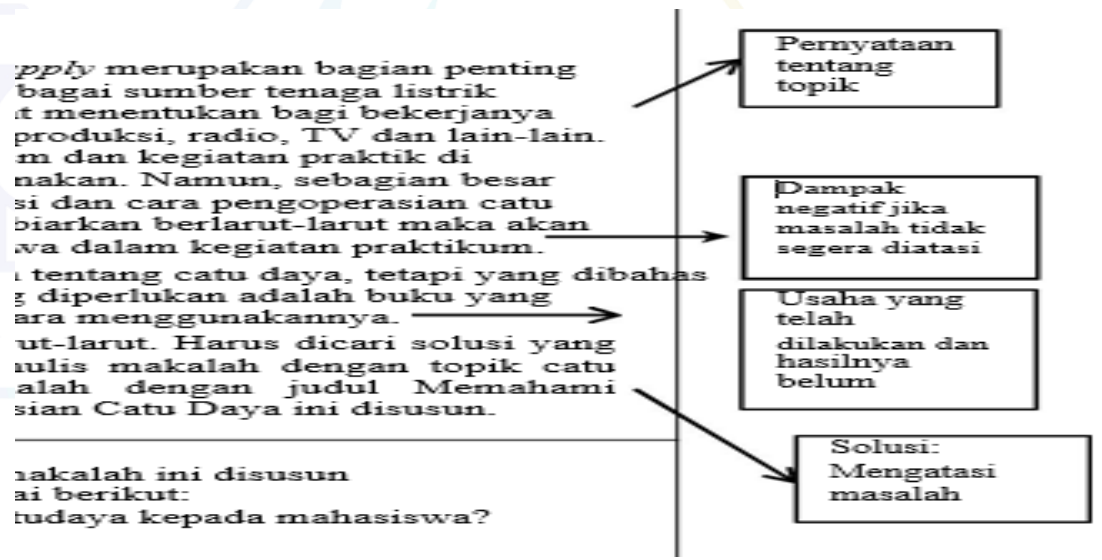

Figure 3. Marginal Note

The next activity after observing the scientific works texts is designing scientific work. There are two processes in designing scientific work: (1) selecting and limiting the topic and (2) creating the framework of scientific work. Selecting and limiting the topic is the basic things in designing scientific work; in this stage, the definition of the term used, the method in designing the scientific work, and the method to limit the topic of scientific should be presented in order to give a clear explanation of the activity. The following picture provides the steps of selecting and limiting the topic of scientific work. 
ISLLAC

Journal of Intensive Studies on Language, Literature, Art, and Culture

Vol. 1 No. 1 September 2017

The next learning activity is the practice of selecting and limiting the topic of scientific work. In this section, the students set their own selected topics by aligning it with the requirement of topic selection. The practice of selecting and limiting topics should be done based on pre-defined steps. In the practice stage, the students can work independently and also collectively. After that, the students present their results to the others. The students can also flexible ask questions and give feedback. The lecturer plays a role as a facilitator who provides reinforcement of the learning material so that the students can gain a complete understanding of how selecting and limiting the topic of scientific work.

The results of the students in selecting and limiting the topic also can be selfassessed by the students themselves by utilizing the instruments that have been provided. By this instrument, it allows the students to know the mistake and then fix it by themselves. The instruments used to assess the results of practice can be seen in the following figure.

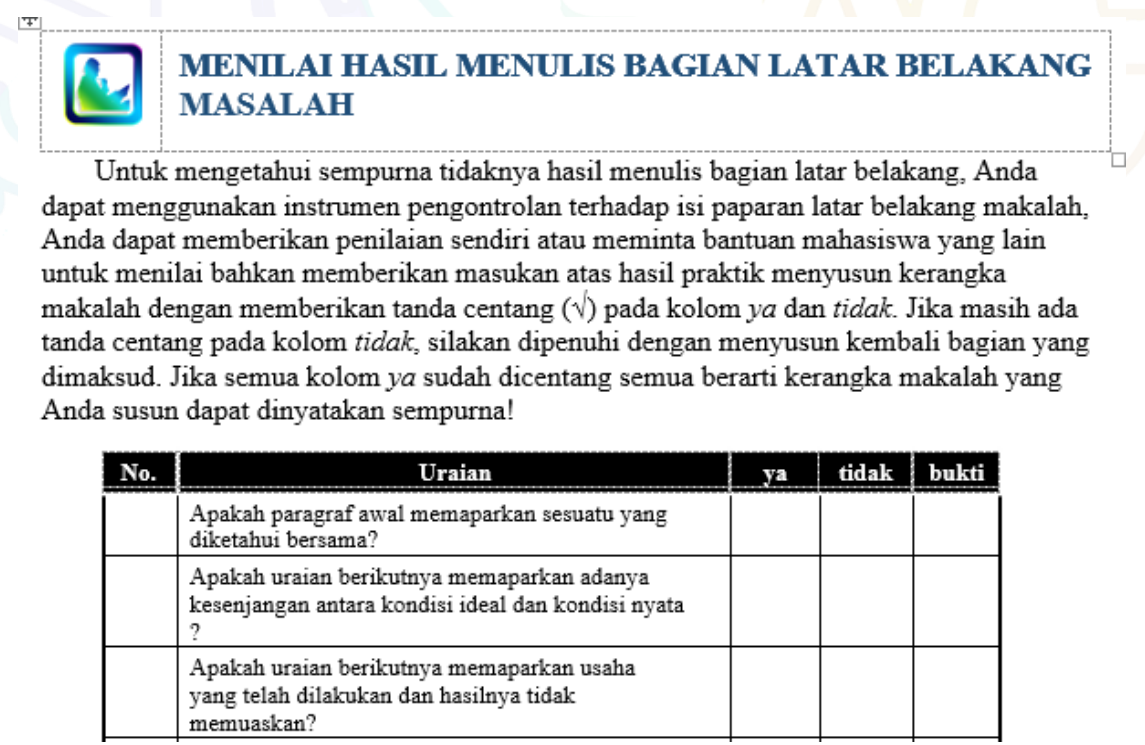

Figure 4. Assessing the practice results. 
ISLLAC

Journal of Intensive Studies on Language, Literature, Art, and Culture

Vol. 1 No. 1 September 2017

The next activity is constructing the framework of scientific work. There are two activities in constructing the framework of the scientific work: (1) the steps to develop the framework of scientific work and (2) the practice to develop the framework of scientific work. The learning activities in this activity are much the same as the activities of selecting and limiting the topic. The practice of constructing a framework of scientific work is done based on the steps of preparing a framework of scientific work. Independent and collective activities, assessing the results of the work using the instrument, and the reinforcement provided by the lecturers are also entailed in this section.

The next step is learning how to write a scientific paper including the steps to write the introduction, the discussion, the conclusion, and the list of references.

The steps of writing a scientific paper present the procedure of writing a scientific work. In order to achieve a fully potential competence from practical activities, the steps of scientific work writing should be aligned with the standard procedures. Every procedure should be followed by the students. The following figure provides the procedure of writing a scientific paper.

\section{La LANGKAH MENULIS BAGIAN PEMBAHASAN}
1. Cermati kembali rumusan tujuan di bab 1 !
2. Tentukanlah setiap rumusan tujuan menjadi topik pembahasan!
3. Topik-topik itu menjadi sub-sub topik!
4. Jabarkan topik dan subtopik itu menjadi pemaparan yang baik.
5. Kutipan ditulis sesuai kaidah yang tepat sesuai dengan $B A B 5$.
6. Suntinglah bahasanya sesuai dengan kaidah seperti pada BAB 6 .

Figure 5 The steps of writing

The next activity is the practice of composing scientific works. Activities undertaken by students include (1) writing commands by following the procedures outlined in the standard writing scientific papers, (2) discussing, and (3) examining 
ISLLAC

Journal of Intensive Studies on Language, Literature, Art, and Culture

Vol. 1 No. 1 September 2017

the results of practice using instruments. The practices and instruments in composing the scientific papers can be seen in the following figure.

国

\section{PRAKTIK MENULIS BAGIAN PENUTUP}

Tulislah bagian penutup berdasarkan panduan berikut ini.

1. Tulislah bagian penutup (simpulan dan saran) dengan mengikuti langkah menulis bagian penutup.

2. Mintalah teman Anda untuk memberikan saran dan masukan berdasarkan instrumen yang telah disediakan.

3. Berdasarkan masukan dari teman Anda, susun kembali bagian penutup.

4. Sebelum diserahkan kepada dosen, teliti secara cermat bagian penutup yang Anda buat berdasarkan instrumen yang telah disiapkan

5. Jika kesimpulan dan saran yang Anda susun sudah sesuai dengan instrumen, silakan diserahkan kepada dosen pengampu untuk dinilai.

Kemahiran Anda dalam menulis bagian penutup sudah pasti akan Anda peroleh jika Anda berlatih terus-menerus. Jangan khawatir jika pada tulisan pertama masih banyak kesalahan. Pada tulisan yang kedua dan seterusnya tentu akan lebih baik dibandingkan dengan tulisan-tulisan sebelumnya.

Figure 6 The Practice of Writing Closing Part

\section{MENILAI HASIL MENULIS}

BAGIAN PENUTUP

Untuk mengetahui sempurna tidaknya hasil praktik Anda dalam menulis bagian penutup, Anda dapat memberikan penilaian sendiri atau meminta bantuan mahasiswa yang lain untuk menilai bahkan memberikan masukan atas hasil praktik menyusun kerangka makalah dengan memberikan tanda centang $(\sqrt{ })$ pada kolom ya dan tidak. Jika masih ada tanda centang pada kolom tidak, silakan dipenuhi dengan menyusun kembali bagian yang dimaksud. Jika semua kolom ya sudah dicentang semua berarti kerangka makalah yang Anda susun dapat dinyatakan sempurna!

\begin{tabular}{|c|c|c|c|c|}
\hline No. & Uraian & ya & tidak & bukti \\
\hline 1. & $\begin{array}{l}\text { Apakah kesimpulan yang Anda susun merupakan } \\
\text { penegasan atau merupakan kesimpulan dalam paparan } \\
\text { bagian pembahasan? }\end{array}$ & & & \\
\hline 2. & $\begin{array}{l}\text { Apakah saran yang Anda susun relevan dengan } \\
\text { paparan dalam pembahasan? }\end{array}$ & & & \\
\hline & $\begin{array}{l}\text { Apakah saran yang Anda susun mengacu kepada } \\
\text { siapa saran ditujukan? }\end{array}$ & & & \\
\hline
\end{tabular}

Figure 7 Assessing the Writing 
ISLLAC

Journal of Intensive Studies on Language, Literature, Art, and Culture

Vol. 1 No. 1 September 2017

\section{CONCLUSIONS AND SUGGESTIONS}

The learning materials for writing scientific works for Polytechnic students include 5 skills: (1) writing scientific works, (2) writing scientific articles, (3) writing apprentice work reports, (4) quoting and writing reference lists, and (5) editing language employed in scientific works.

The product developed in this research is a relevant learning material to write scientific works for Polytechnic students. This can be seen from the practice activities that represent the hallmark of Polytechnic education. To support the practical activities, the learning steps encompass observing the text, understanding the steps of writing scientific papers, practicing writing scientific papers, and assessing the results of the writing.

Based on the foregoing presentation of results and discussion, the following are suggestions for its utilization, dissemination, along with recommendations for future research and further development. For lecturers teaching Indonesian, they can use this product as one of the learning materials in writing scientific works for three reasons: first, based on the results, this research product can be accounted academically and conceptually. Therefore, it also improves the students' ability in writing scientific works. Secondly, based on the results of the effectiveness test, it reveals that the writing material of this scientific works can improve the ability to write scientific papers.

The supervisors of the Student Activity Unit (UKM) of Academic Division can utilize this research and development products as one of the models in developing scientific writing activities for two reasons: first, this research and development product tender teaching materials to write scientific papers that is relevant to the education system at Polytechnic Institute; secondly, this research and development products offer learning materials for scientific works writing on which it proceeds with pre-writing activities, writing activities, and post-writing activities. 
ISLLAC

Journal of Intensive Studies on Language, Literature, Art, and Culture

Vol. 1 No. 1 September 2017

Thus, it is expected that those three steps of process-oriented writing can fully enhance the student's ability and potential in writing scientific works.

The elements in charge for maintaining the development of learning in Polytechnic, for instance, P3AI, are suggested to use this result of this research and development endeavor as one of the development model of learning materials in Polytechnic.

This learning material has not been validated by experts and practitioners to test its effectiveness. Given the importance of the students' ability to write scientific works and the complexity of writing skills, therefore, it is recommended for future research to validate and test the effectiveness of this research product. By validating and testing the effectiveness of the product, it will obtain an ideal learning material as an effort to improve academic writing skills for Polytechnic students.

\section{REFERENCES}

Biggs, J.B. (1987). The Proses of Learning. Sydney: Prentice-Hall of Australia

Borg, W.R, and Gall, M.D. (2003). Educational Research An Introduction (7th Edition).New York: Longman Inc.

Borg, W.R., and Gall, M.D. (2003). Education Research. White Plains: Longman Inc.

Ellis, A. (1989). Elementary Language Art Instruction. New Jersey: Englewood Cliff.

Heffernan, JAW. dan JE Lincoln.(1990). Writing: A College Handbook. New York: WW Norton \& Company.

Keputusan Direktur Jenderal Pendidikan Tinggi Departemen Pendidikan Nasional Republik Indonesia Nomor : 43/Dikti/Kep/2006 Tentang Rambu-Rambu Pelaksanaan Kelompok. Matakuliah Pengembangan Kepribadian di Perguruan Tinggi.

MacArthur, C.A. dan Jill Fitzgerald. (2007). Best Practices in Writing Instructional. New York: The Guilford Press.

Moodie, G F. (2008). From Vocational to Higher Education. England: McGraw-Hill House. 
ISLLAC

Journal of Intensive Studies on Language, Literature, Art, and Culture

Vol. 1 No. 1 September 2017

Thamrin, Moh. (2014). Menulis Baban Ajar Menulis Karya Ilmiah bagi Mahasiswa Vokasional.

Temple, C. Ch.; R. Nahan; N Burn; and F Temple. (1988). The Beginning of Writing. Boston: Allyn and Bacon Linc.

Tompskin, G E., and Kennet Hosskisson.(1995). language Arts Contents and Teaching Strategies. New York: Macmilling College Publishing.

Trilaksono, S. (2005). "Pendidikan yang Memberdayakan" Disampaikan dalam seminar pendidikan dalam rangka launching Sekolah Alam Insan Mulia Surabaya tanggal 5 Desember 2005.

Wahab,A. and Lestari. (1999). Menulis Karya Ilmiah. Surabaya: Penerbit Universitas Airlangga Press.

Willis, J. (1995).A Recursive, Reflective Instructional Design Model Based Constructivist-Interpretivist Theory. Educational Technology, (online), 35 (6), 5 23, reviewed on 19 September 2012.

World Bank. (1989). Indonesia: Basic Education Study. Washington DC: World Bank. 